\title{
STEM integration in classroom practices among Biology teachers in MARA Junior Science College (MJSC)
}

\begin{abstract}
The purpose of this study is to explore the teacherô understanding and practices of STEM integration in Biology classrooms at MARA Junior Science College (MJSC). A semistructured interview was conducted with five Biology teachers from three different MJSC. These teachers were purposefully selected from teachers who integrated STEM in their classrooms. The aim of this study is to explore the Biologyôs teachersôunderstanding about STEM integration and how they practice STEM integration in their classroom despite all the challenges faced by them. Data was analysed using a comparative method based on the results of the interview. Findings from the interview suggest that, firstly, student-centred activities are the keys to integrate the four disciplines of STEM in the classroom. Secondly, all five teachers understand STEM as the integration of Science, Technology, Engineering and Mathematics in Biology. Thirdly, there are four main challenges faced by the teachers in order to integrate STEM which are: time constraint, lack of teaching aids, lack of professional trainings in STEM and studentsôattitude in the classroom. Lastly, all the teachers agree that STEM integration will change the attitude of their students towards Biology.
\end{abstract}

Keyword: STEM integration; Teachers' understanding; Classroom practices; Biology education; Challenges 